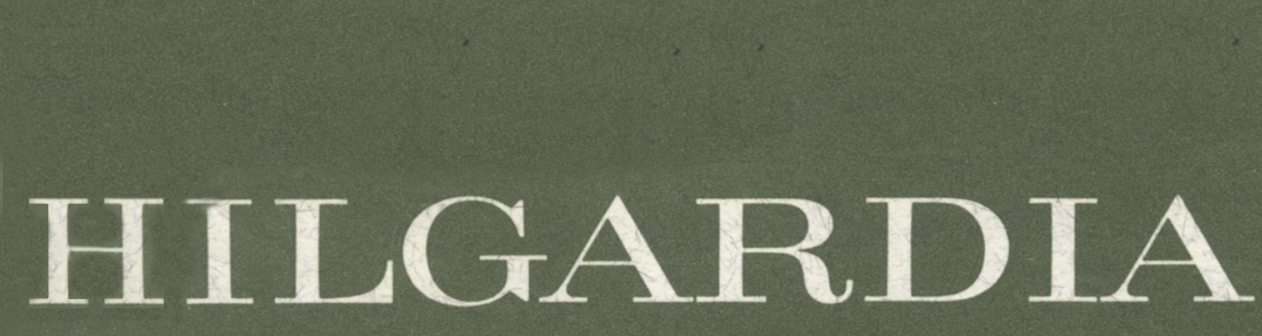

A JOURNAL OF AGRICULTURAL SCIENCE PUBLISHED BY THECALIFORNIA AGRICULTURAL EXPERIMENT STATION

Volume $50 \bullet$ Number $4 \cdot$ August, 1982

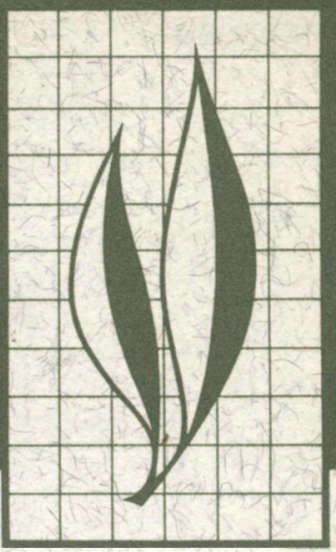

\title{
Factors Affecting Vegetation
}

\section{on a Serpentine Soil}

\section{Principal Components Analysis of Vegetation Data}

Robert L. Koenigs, William A. Williams, and Milton B. Jones

\section{Chemical Composition of Foliage and Soil}

Robert L. Koenigs, William A. Williams, Milton B. Jones, and Arthur Wallace 


\section{Principal Component Analysis of Vegetation Data}

Vegetation of $\mathbf{4 0}$ sample stands on serpentine soils was analyzed and used to indicate conditions that might limit the establishment of annual range species. Two groups of stands, "cypress" and "noncypress," were defined by cluster analysis. Stands with Cupressus sargentii also contained Arctostaphylos viscida and occurred on mesic sites with lower $C a$ in the sub-surface soil. Stands without $C$. sargentii usually contained Adenostoma fasciculatum and Quercus durata and occurred on the drier sites with higher $\mathrm{Ca}$.

Principal component analysis was carried out on the vegetation data in each group of stands, and simple and partial correlations were calculated between principal components and environmental variables. A moisture gradient within the cypress stands was associated mainly with the water-storage capacity of the soil. Cupressus sargentii was more abundant at lower water-storage capacities (and at lower elevations), while Arctostaphylos viscida was most abundant at the opposite end of the gradient. No correlations were found with soil chemical analyses.

The relations between principal components and environmental variables were less apparent within the non-cypress stands. Adenostoma fasciculatum and Garrya congdoni were most abundant where Ca contents in the soil were high while Ceanothus jepsonii, Quercus durata, Bromus laevipes, and Sisyrinchium bellum were most abundant at the opposite end of the gradient.

\section{THE AUTHORS:}

Robert L. Koenigs was Research Assistant and is now Environmental Consultant, 9232 Lomker Court, Santee, CA 92071. William A. Williams is Professor, Department of Agronomy and Range Science, Davis. Milton B. Jones is Agronomist, Department of Agronomy and Range Science, Hopland Field Station. Arthur Wallace is Professor, Laboratory of Nuclear Medicine and Radiation Biology, Los Angeles. 


\section{Principal Components Analysis of Vegetation Data ${ }^{1}$}

\section{INTRODUCTION}

MANY AREAS OF DEEP-ROOTED chaparral-type vegetation in regions of Mediterranean climate are being converted to a shallow-rooted annual-type vegetation for a variety of reasons: to increase stream flow and extend flow into the summer (Pitt, Burgy and Heady, 1978; Rowe and Reimann, 1961); to facilitate wildfire control; and to improve the habitat for wildlife and livestock (Biswell, 1974). Unsuitable soil conditions, however, often make it difficult to establish an annual herbaceous ground cover. This is especially true on serpentine soils, where adverse soil physical properties, deficiencies of $\mathrm{N}, \mathrm{P}, \mathrm{K}$, $\mathrm{S}$, and $\mathrm{Ca}$, and toxicities of $\mathrm{Mg}, \mathrm{Cr}, \mathrm{Ni}$, and $\mathrm{Co}$ inhibit the establishment of nonendemic species (Proctor and Woodell, 1975).

Soil fertility can be determined by measuring the effects of adding various nutrient elements on introduced species (Jones, Williams, and Ruckman, 1977). However, this usually involves large and costly experiments that must run for several years, that are applicable only to that site, and that may give little indication of spatial variation within the area.

An alternative approach is to relate variations in the existing vegetation to variations in soil conditions (Walker and Wehrhahn 1971; Waring and Major, 1964; Westman, 1975).

This investigation was undertaken to define the environmental gradients in serpentine soils within the Lake Berryessa watershed by studying variation in the vegetation, soil chemistry, and the physical factors affecting availability of water. Stands of vegetation were first objectively divided into two groups by cluster analysis. Simple and partial correlations of environmental variables with principal components of vegetation data were then examined within each group to define the most influential environmental variables affecting the vegetation on a serpentine soil.

\section{Study area}

Two adjacent watersheds, Pocock and Cedar creeks, were studied within the Lake Berryessa watershed (latitude $38^{\circ} 47^{\prime} \mathrm{N}$, longitude $122^{\circ} 22^{\prime} \mathrm{W}$ ). Twenty sample stands were selected randomly within each watershed from areas formerly defined by the Bureau of Land Management (USDI) as suitable for conversion to annual-type vegetation. Within each stand, three transects, each $15 \mathrm{~m}$ long and $7.5 \mathrm{~m}$ apart, were laid out parallel to each other and to the contour of the slope in spring and summer of 1975 with the criterion that vegetation discontinuities be avoided.

The sites are located at elevations ranging from 400 to $680 \mathrm{~m}$ above sea level on soils derived from serpentine bedrock (Conrey, 1947) on slopes ranging from nearly level $\left(2^{\circ}\right)$ to very steep $\left(29^{\circ}\right)$. However, all but four sites are on slopes that fall within the

${ }^{1}$ Accepted for publication April 12, 1982. 


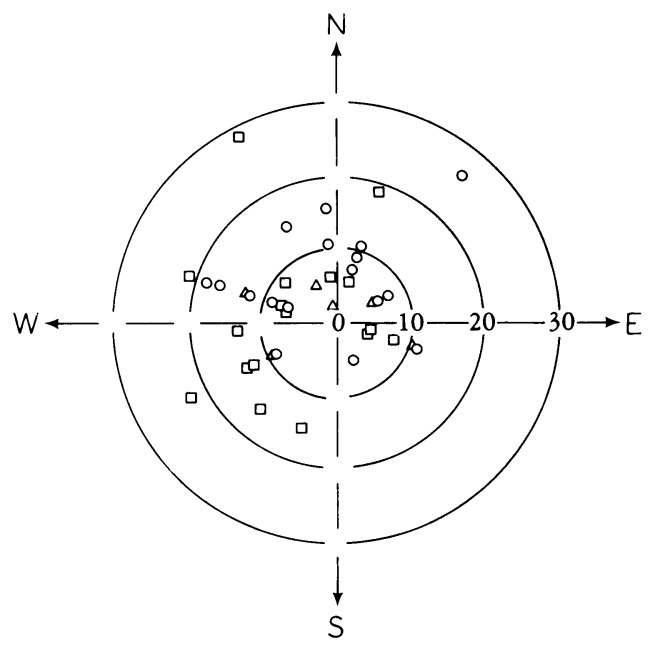

The distribution of sites with respect to aspect and slope. Position of dots on imaginary lines radiating from the center indicates aspect, and distance from the center indicates the angle of slope in degrees. (o, cypress stands; $\Delta$, intermediate stands; $\square$, non-cypress stands).

range of $0^{\circ}$ to $20^{\circ}$. The figure shows the distribution of sites with respect to aspect and slope. Potential solar radiation at each site was calculated as a function of aspect, slope, and latitude for the winter solstice, spring equinox, and summer solstice (Sellers, 1965). Potential solar radiation ranged from 19 to 340 langleys day ${ }^{-1}$ at the winter solstice and 727 to 851 langleys day ${ }^{-1}$ at the summer solstice. Radiation at the spring equinox was almost perfectly correlated with winter radiation.

The majority of soils in the study area were clayey, serpentinitic, thermic, Lithic Rhodoxeralfs, Haploxeralfs, and Argixerolls (Soil Survey Staff, 1972). The most common group was the Lithic Rhodoxeralf, found in 18 of the sites, 14 of which contain cypress stands. The Lithic Argixeroll occurred in 15 sites, 12 of which were occupied by noncypress stands.

\section{MATERIALS AND METHODS}

\section{Soil sampling}

Soil samples were collected from both the A horizon (surface) and the B horizon (subsoil) at two locations along each of the three transects. Depth of the A horizon and of the entire soil profile was measured at each sampling location.

Exchangeable $\mathrm{Na}, \mathrm{K}, \mathrm{Ca}$, and $\mathrm{Mg}$ were extracted from the soil samples with $N$ ammonium acetate and determined by atomic-absorption spectrophotometry. Measurement of $\mathrm{pH}$ was made with a glass electrode on a saturated paste. Percentages of soil particle-size classes were determined on an oven-dry weight basis. Gravel and sand were determined by sieving and washing. Clay fractions were determined by the hydrometer method, and silt was calculated as the difference (\%) remaining after sieving out gravels, sands, and clays. Components were defined as: gravel, $2 \mathrm{~mm}$; sand, 0.05-2 $\mathrm{mm}$; silt, $2 \mu \mathrm{m}$ to $0.05 \mathrm{~mm}$; and clay, both $<.2 \mu \mathrm{m}$ and $<1 \mu \mathrm{m}$. The water-holding capacity of 
the soils was determined at $-1 / 3$ bar (field capacity) and -15 bar (permanent wilting point) by the pressure plate extraction method, and the difference is termed "available water."

Clay, sand, silt, and "available water" are expressed as percentages of both the nongravel portion of the soil and the entire soil (i.e., gravel included). Storage capacity of available water within the entire soil profile was calculated by multiplying the available water content (gravel included) by the soil depth.

\section{Vegetation sampling}

The cover (\%) of each shrub species in a stand was estimated by the line-intercept method. If a species occurred in the stand but was not intercepted by a transect, it was given a cover value of 0.1 percent. Quadrats $(3 \times 15 \mathrm{~m})$ were centered over each transect to determine the density of the five most abundant species: Cupressus sargentii, Arctostaphylos viscida, Quercus durata, Adenostema fasciculatum, and $C$. jepsonii (nomenclature follows Munz and Keck, 1959). The height of all A. viscida and C. sargentii plants within each quadrat and the basal circumference of $C$. sargentii were measured.

Ring counts were used to determine the age of Cupressus sargentii. This species generally occurred in even-aged stands, but in three cases where there were age differences, the most common age was used in further analyses.

The herbaceous, or understory, vegetation was generally quite sparse, and no estimates were made of its cover. Instead, four $1-\mathrm{m}^{2}$ quadrats were spaced evenly along each transect. All understory species occurring within each quadrat were noted. A species was given a value of one (if it occurred in the site) plus the number of quadrats it occurred in, giving a range of values from zero to 13 .

\section{Statistical methods}

Stands were divided objectively into two groups ("cypress" and "non-cypress") by an agglomerative method of cluster analysis (Williams, 1971) due to an obvious discontinuity in the distribution of species (Appendix). The cluster analysis was based upon a similarity matrix calculated according to:

$$
\operatorname{Similarity}_{(\mathrm{jk})}=200 \frac{\sum^{\mathrm{i}} \min \left(\mathrm{P}_{\mathrm{ij}}, \mathrm{P}_{\mathrm{ik}}\right)}{\stackrel{\mathrm{i}}{\Sigma}\left(\mathrm{P}_{\mathrm{ij}}+\mathrm{P}_{\mathrm{ik}}\right)}
$$

where $j$ and $k$ are pairs of stands, $i$ is species, and $P_{i j}$ is a measure of species $i$ in stand $j$. Two measures of species were used and compared: 1) percentage cover for shrubby species or number of occupied quadrats for herbaceous species, and 2) presence-absence data. Resulting coefficients for each stand comparison are referred to as percentage similarity (PS) in the first case and coefficient of community (CC) in the second (Gauch and Whittaker, 1972). The means of environmental variables for the groups of stands were compared with a t-test.

Principal component analysis (PCA) was made on correlation matrices of species abundance and size variables (Nie et al. 1975), and the resultant axes were then correlated with environmental variables (Walker and Wehrhahn, 1971; Westman, 1975). 
Partial correlation coefficients were also calculated for each principal component (PC) with each environmental variable while holding variables having significant simple correlations constant (one at a time). For simplicity, we have included in Table 4 only those partial correlations that resulted in a pair of environmental variables that together accounted for the most variation in the PC. PCA was performed separately on brush species and understory species, when understory species were present in sufficient number-that is, in non-cypress stands.

\section{RESULTS}

\section{Vegetation in the study area}

Stands of vegetation in the study area ranged from being very similar to each other to having no species in common. Arctostaphylos viscida and Quercus durata were the only species to occur in more than 30 of the 40 stands. Only five other species occurred in more than half the stands: Ceanotbus jepsonii, Galium andrewsii, Galium nuttallii, Adenostema fasciculatum, and Heteromeles arbutifolia. A group of six intermediate stands was associated with both cypress and non-cypress stands, depending upon which measure of similarity was used (PS or CC). Cypress stands are composed primarily of Cupressus sargentii and Arctostaphylos viscida, with little or no understory. The noncypress stands consisted of Arctostaphylos viscida, Quercus durata, and Adenostema fasciculatum, with considerably more understory species. Intermediate stands have no Cupressus sargentii, have a very high cover of Arctostaphylos viscida, contain both Adenostema fasciculatum and Quercus durata, and tend to have more understory than the cypress and less than the non-cypress stands.

\section{Soil properties in the study area}

The $\mathrm{pH}$ of all soils ranged from 6.2 to $6.8(\overline{\mathrm{x}}=6.6)$ with no significant difference due to depth. Soil depth was from 20 to over $60 \mathrm{~cm}(\overline{\mathrm{x}}=31 \mathrm{~cm})$ with the A horizon ranging from less than 2 to $7 \mathrm{~cm}$. Potassium and $\mathrm{Ca}$ were quite low in all soils and were especially low in the subsoil, where they had means of 0.66 and $3.84 \mathrm{meq} / 100 \mathrm{~g}$, respectively. Subsoil Ca was variable, however, ranging from 0.54 to $9.65 \mathrm{meq} / 100 \mathrm{~g}$. Magnesium was abundant in the subsoil with a mean of $31.9 \mathrm{meq} / 100 \mathrm{~g}$ and a range of 18.9 to 45.8 $\mathrm{meq} / 100 \mathrm{~g}$. Calcium to magnesium ratios ranged from 0.07 to $0.71(\overline{\mathrm{x}}=0.28)$ in the surface and 0.01 to $0.38(\overline{\mathrm{x}}=0.13)$ in the subsoil.

\section{Comparison of cypress and non-cypress environments}

Table 1 gives the means and standard errors of the environmental variables for the groups of stands formed by both methods of cluster analysis. The environmental variables that best distinguished one group from another for both methods of clustering were surface clays $(<1 \mu \mathrm{m})$, field capacity of surface soil, elevation, and subsurface $\mathrm{Ca}$ concentration. The cypress stands occurred on sites that had less surface clay, held more water in the surface, occurred at higher elevations, and contained less subsoil $\mathrm{Ca}$. Surface silt, PWP, and subsoil clay also differed significantly between the cypress and 
non-cypress stands as defined by both clustering methods. (No subsequent reference to cypress and non-cypress stands includes intermediate stands.)

Cypress stands also tend to occur more frequently on northerly exposures (Fig. 1). Fourteen of 26 sites with a northerly component to their aspect were among the cypress stands, while only three of 14 with a southerly component belonged to the cypress group. The tendency for cypress stands to occur both at higher elevations and on northerly slopes indicates an adaptation to the more mesic of the conditions found in this study. Others have also noted the presence of Cupressus sargentii in locally moist areas (Hardham, 1962; Griffin and Stone, 1967).

\section{Age of the cypress stands}

Two stands (27 and 28) were found to be 36 years old when one year was attributed to each ring. Seven stands were between 86 and 105 years old, and the remaining eight ranged from 123 to 130 years old. Correlations between species variables and age of the cypress stands were not significant when the two youngest stands were excluded. When these stands were included, the significant correlations reflected size increases and the disappearance of Ceanothus jepsonii from older stands. Correlations are not reported due to the poor distribution of stand age in our data.

\section{Principal components}

A separate principal component analysis was performed on the understory species in the non-cypress stands because of the number of species. Three principal components were extracted for each analysis. Tables 2 and 3 give the loadings (equivalent to simple correlation coefficients) for each variable and indicate the eigenvalue and percentage of variation accounted for by each component and the total variation accounted for by all three components.

a) Cypress stands. The first PC $\left(\mathrm{C}_{1}\right)$, which contrasts the cover and density (negative loadings) of Arctostaphylos viscida with nearly all other variables for all other species, accounts for 37.2 percent of the variation in the cypress variable set (Table 2). This component is correlated negatively with elevation and subsoil water-holding properties (Table 4a). Correlations of $\mathrm{C}_{1}$ with surface and subsoil sand $(+)$ and water-holding properties in the subsoil $(-)$ are significant when the effect of elevation is controlled (i.e., partial correlations, or correlations at a fixed elevation). Elevation and available water in the subsoil together account for 75 percent of the variation of this first PC and define a moisture gradient. Arctostaphylos viscida dominated the vegetation at the higher elevations and/or higher-storage-capacity sites, while Cupressus sargentii, Galium andrewsii, and Quercus durata are more abundant in the "drier" sites.

In $\mathrm{C}_{2}$, the size (cover/individual) of Quercus durata and Ceanothus jepsonii and cover and density of Cupressus sargentii (negative loadings) are contrasted with the size of Cupressus sargentii and height and cover of Arctostaphylos viscida (Table 2). This component is correlated positively with potential summer solar radiation and subsoil clay and silt, and correlated negatively with subsoil sand and potassium (Table 4a). These environmental correlations, however, are due to the position of site 27 , which lies well away from the other sites on this principal component. Omission of this site results in significant negative correlations only with surface clays $(<1 \mu \mathrm{m})$ and gravels. 
Table 2. Loadings (equivalent to correlation coefficients) of species variables on principal components for cypress st ands.

\begin{tabular}{lrrr}
\hline Species variables & $C_{1}$ & $C_{2}$ & $C_{3}$ \\
\hline Cupressus sargentii & & & \\
\hline Cover \% & .79 & -.45 & -.08 \\
Avg. height & .56 & .78 & .11 \\
Density & .03 & -.89 & -.21 \\
Cover/individual & .12 & .63 & .46 \\
Basal area/plot & .78 & .05 & -.06 \\
Basal area/individual & .22 & .64 & .36 \\
Arctostaphylos viscida & & & \\
\hline Cover\% & & & \\
Avg. height & -.54 & .63 & -.04 \\
Density & .70 & .60 & -.17 \\
Cover/individual & -.87 & -.10 & .15 \\
Quercus durata & .74 & .08 & .17 \\
\hline Cover \% & & & \\
Density & .82 & -.24 & .39 \\
Cover/individual & .77 & .04 & .23 \\
Ceanothus jepsonii & .64 & -.70 & .21 \\
\hline Density & & & \\
Cover/individual & -.04 & -.28 & .58 \\
Zigadenus fremonti & .02 & -.80 & .23 \\
Galium andrewsii & .51 & .24 & -.63 \\
Eigenvalue & .83 & -.07 & -.32 \\
\% variation & & & \\
Total \% & 6.33 & 4.51 & 1.62 \\
\hline & & 73.3 & 9.6 \\
\hline
\end{tabular}

$\mathrm{C}_{3}$ contrasts Ceanothus jepsonii density with Zigadenus fremonti abundance (Table 2). This component is correlated with the depth of the surface horizon, available-water storage potential in the surface soil (both +), and subsoil Ca (-) (Table 4a). Partial correlations with subsoil silt and gravels were significant when the effect of surface depth was controlled. $C_{3}$ appears to be an internal drainage gradient that proceeds from a shallow surface soil with a low water storage capacity and a subsoil with little silt and much gravel to a deep surface soil and a subsoil with a lot of silt and little gravel. Surface depth and subsoil gravels account for 54 percent of the variation in $\mathrm{C}_{3}$ (Table 4a). Ceanothus jepsonii is more dense and Zigadenus fremonti less abundant on sites where the soil can hold more moisture.

b) Non-cypress stands. The cover of Adenostema fasciculatum, Garrya congdoni, and Heteromeles arbutifolia contrasts with all other variables in the first principal component $\left(\mathrm{N}_{1}\right)$ (Table 3 ). This component was significantly correlated with both surface and subsoil $\mathrm{Ca}$ and $\mathrm{Ca} / \mathrm{Mg}$ ratios and with surface $\mathrm{K}$ and $\mathrm{Mg} / \mathrm{Ca}$ ratio (Table $4 \mathrm{~b}$ ). A significant partial correlation with surface gravel was found only when the effect of surface $\mathrm{Ca}$ was controlled. The cover of Adenostema fasciculatum was greater and that of Ceanothus jepsonii was less where Ca was high and surface gravels were low.

The size (cover/individual) of Adenostema fasciculatum and Ceanothus jepsonii and cover of Quercus durata (negative loadings) were contrasted with cover, height, and density of Arctostaphylos viscida in $\mathrm{N}_{2}$ (Table 3). This component was correlated with the two measures of surface sand and had a significant positive partial correlation with depth of the surface horizon when the effect of sand was controlled (Table 4b). Arctos- 


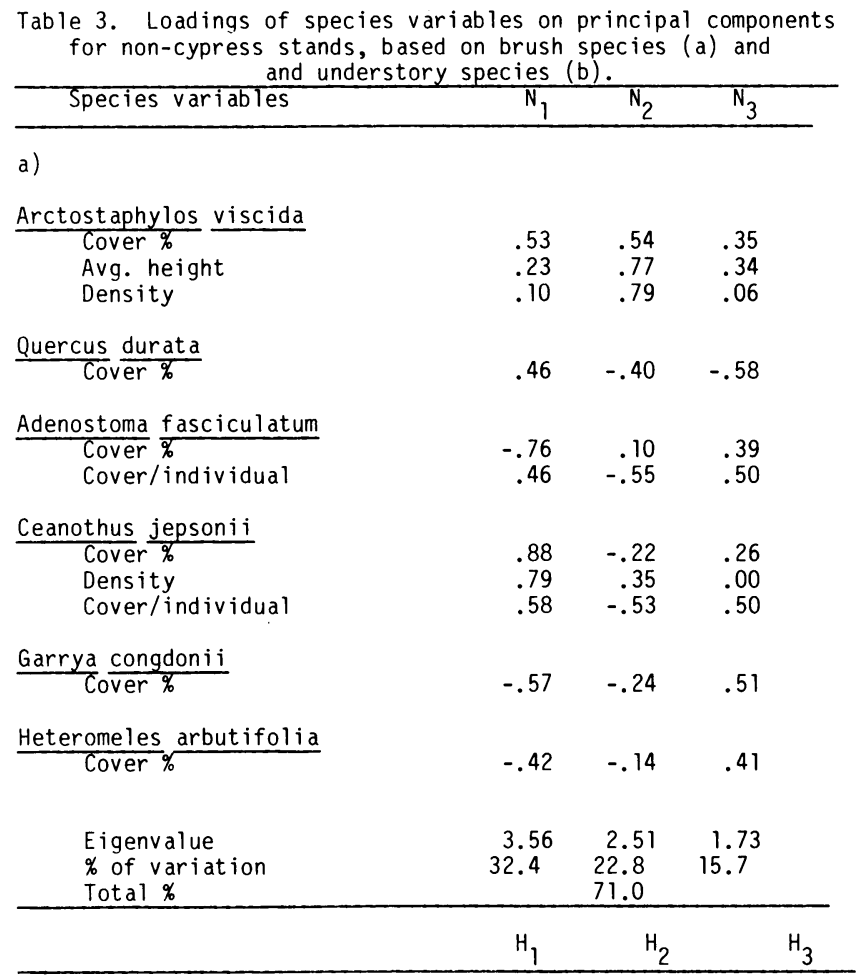

b)

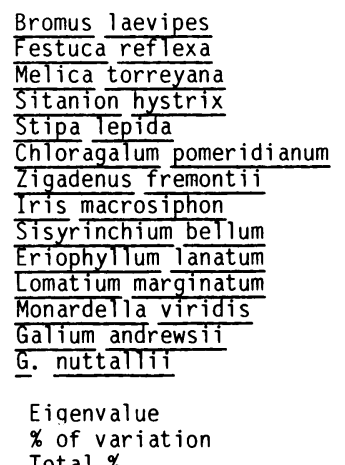

$\begin{array}{rrr}.85 & -.11 & .26 \\ .65 & -.33 & .10 \\ .52 & -.35 & -.46 \\ .49 & -.10 & -.71 \\ -.10 & .44 & -.09 \\ .62 & .54 & -.15 \\ -.41 & -.33 & .12 \\ .46 & -.37 & -.43 \\ .80 & .36 & .08 \\ .67 & -.11 & .27 \\ -.23 & .56 & .35 \\ .38 & .00 & .68 \\ .24 & .66 & -.39 \\ .69 & -.27 & .43 \\ & & \\ 4.33 & 2.49 & 2.04 \\ 28.9 & 16.6 & 13.6\end{array}$

taphylos viscida was more abundant and larger where the soil had a greater proportion of sand and a deeper surface horizon.

$\mathrm{N}_{3}$ is a contrast of Quercus durata cover with all other variables (Table 3). This component was correlated negatively with both surface and subsoil silt (Table $4 \mathrm{~b}$ ). We found only one signficant partial correlation, with subsoil gravel, when surface silt was controlled. The cover of Quercus durata was greater where silt and subsoil gravel were greater.

The first principal component for the herbaceous species $\left(\mathrm{H}_{1}\right)$ had primarily positive loadings, indicating that for the most part the understory species varied in the same direction (Table 3). Bromus laevipes and Sisyrinchium bellum had the highest loadings. $\mathrm{H}_{1}$ was correlated with surface $\mathrm{Ca}$ and $\mathrm{Ca} / \mathrm{Mg}$ ratio and subsoil $\mathrm{Mg}$ and $\mathrm{Ca} / \mathrm{Mg}$ ratio (Table $4 \mathrm{~b}$ ). These correlations were similar to those for $\mathrm{N}_{1}$, although $\mathrm{H}_{1}$ was not cor- 
Table 4a. Significant $(P .05)$ simple $(r)$ and partial $\left(r_{y 2.1}\right)$ correlations of principal components with environmental variables ( $\star$ indicates $P<.01$ ); the variable controlled for in the calculation of partial correlation coefficients is indicated by a subscript of 1 .

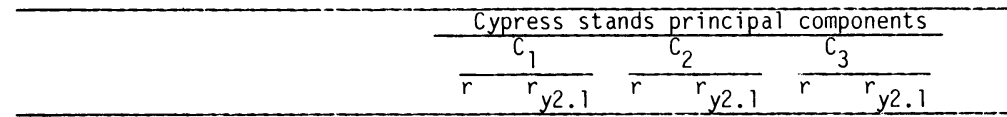

Site characteristics:

Potential solar radiation

1 (langleys/day): winter

2 summer

4 Depth surface horizon $(\mathrm{cm})$

$-.75_{1}^{\star}$

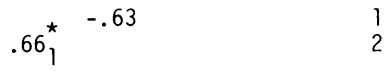

Soil textural composition (\%)

Surface:

8 Without gravels: sand

11 Gravels included: sand

.55

Subsoil:

Without gravels: sand

Gravels included: clay $<1 \mu m$

sand

silt

-.52
.52

.52

.52

gravel

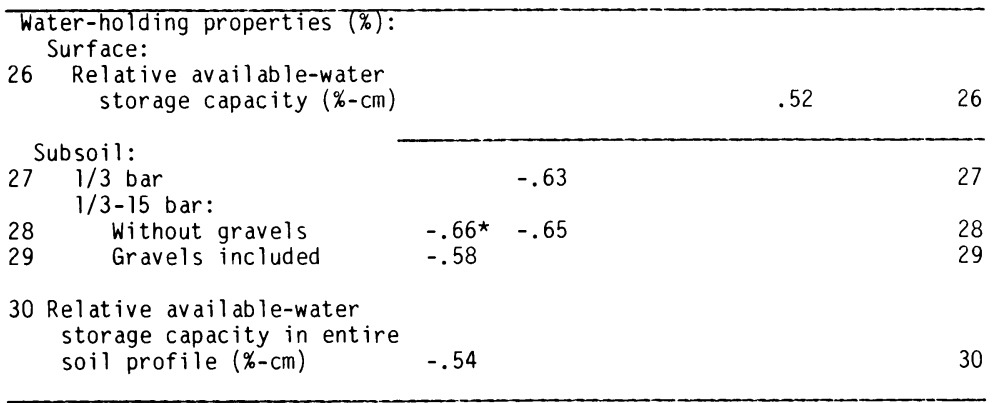

Chemical properties:

Subsoil:

$35 \mathrm{~K}$ (meq/100 g)

$36 \mathrm{Ca}$ (meq/100 g)

$\begin{array}{lll}-.64 * & -.55 & 35 \\ & -.51 & 36\end{array}$

$\mathrm{R}^{2}$

.75

.66

.54

related significantly with $\mathrm{N}_{1}(\mathrm{r}=0.41)$. There were no significant partial correlations. Herbaceous vegetation tended to be more abundant where soil Ca was less abundant.

The only large loadings for $\mathrm{H}_{2}$ were positive ones with Galium andrewsii, Lomatium marginatum, and Chloragolum pomeridianum (Table 3). $\mathrm{H}_{2}$ was correlated positively with both surface and subsoil clay and with subsoil $\mathrm{Ca}$ and correlated negatively with surface field capacity (Table 4b). Only one significant partial correlation, with subsoil $\mathrm{Ca}$, could be found when surface field capacity was controlled.

$\mathrm{H}_{3}$ which is primarily a contrast between Sitanion hystrix and Monardella viridis (Table 3), was correlated significantly with surface water-holding properties, subsoil $\mathrm{K}$, and potential winter solar radiation (Table $4 \mathrm{~b}$ ). We found a significant partial correlation only with potential winter radiation, when the effect of surface storage capacity was controlled. $M$. viridis was more abundant where the surface soil had a large capacity for water storage and on slopes that received little winter radiation. 
Table 4b. (continued).

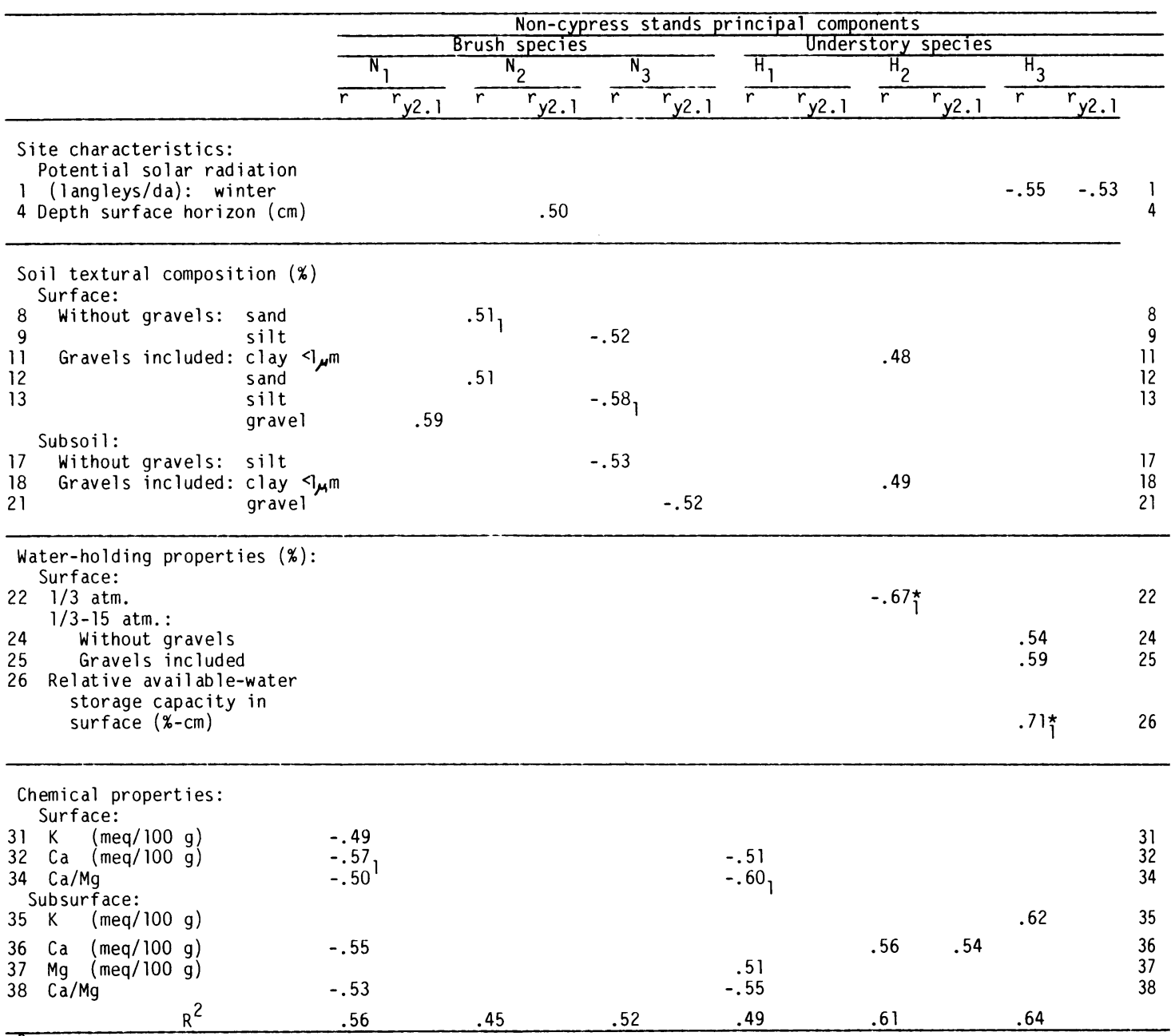

$\mathrm{R}^{2}$ values refer to the proportion of variance accounted for by the variable controlled for and the variable with the best partial correlation.

\section{DISCUSSION AND CONCLUSIONS}

Linear methods of analysis are generally considered inappropriate for studies of the relations of vegetation to environmental gradients because of the theoretical bell-shaped distribution of species along such gradients (Austin and Noy-Meir, 1971; Beals, 1973; Van Groenwoud, 1976). Those same workers, however, agree that linear methods are acceptable where the range of environmental variation in the sites under consideration is sufficiently narrow. All the sites in this study were on soils derived from serpentine bedrock, within an area with only about a $2.5-\mathrm{km}$ radius, over a narrow elevational range, and only on the gentler slopes having a cover of woody vegetation. In addition, 
the sites were divided into two groups on the basis of vegetation in a way that significantly reduced the environmental variability within each group relative to the entire set of sites (Table 1). Therefore, it was assumed that linear methods of analysis would be adequate for identifying important environmental gradients.

An anlysis of this sort can still be rather cumbersome and difficult to interpret. The number of species and environmental variables can quickly become unmanageable making methods of data reduction highly desirable. Identification of important environmental factors can be further complicated by the individualistic nature of vegetation. This concept of vegetation allows for the possibility that each species will be distributed independently on a different environmental gradient (Gleason 1926). However, where the environment is relatively harsh, it is likely that a dominant environmental gradient will exist that will affect most species to some degree at least.

The problem lies in how to identify this unknown gradient. Even when the gradient is known, the best measure of it may not be obvious (Spoomer, 1973). Loucks (1962) addressed the problem by constructing "environmental" parameters measuring different components of the desired gradients. This procedure is probably best used when the data vary considerably and no gradients are suspected. Some researchers have performed ordination on a set of environmental variables and then attempted to interpret the axes as complex gradients (Tracey, 1969; Webb, 1969; Moore and Russell, 1976). The approach to this kind of problem that is probably used most widely is to ordinate the vegetation data in some way and find environmental variables that correlate with the resultant axes (Gemborys, 1974; Walker and Wehrhahn, 1971; Westman, 1975). This method allows the vegetation to define the gradients. We have used the latter approach in this paper.

Principal-component analysis is a method of ordination that is useful for data reduction and hypothesis generation (Williams, 1976) where an underlying factor is considered to be responsible for variation in the data set (Rummel, 1970). An environmental gradient would be a likely underlying factor affecting variation in vegetation data. Any single environmental measurement, however, is not likely to describe that environmental gradient fully.

We sought a pair of environmental variables for each principal component such that: 1) at least one was correlated significantly with the PC, 2) the two could explain significantly more variation in the PC than either variable alone and more than other pairs, and 3) the two could be considered components of a common gradient. The objective was not to describe gradients fully but to propose hypothetical gradients of major importance to the vegetation.

The data-reduction capability of PCA was effective. The first three principal components accounted for 73 percent of the variation in the cypress stands (Table 2). In the non-cypress stands, the first three components accounted for 71 percent of the variation in the set of shrub-species variables but only for 59 percent of that in the herbaceous set (Table 3).

The first and third components of the cypress variable set are apparently the most successful examples of the approach used here. We were able to find interpretable pairs of environmental variables that accounted for 75 and 54 percent, respectively, of the variation in these two PC (Table 4a). Both gradients were related to moisture.

It is not surprising that moisture gradients were important in this semi-arid environment, but it is surprising that soil chemical variables were not important within the cypress stands since $\mathrm{Ca}$ concentrations and $\mathrm{Ca} / \mathrm{Mg}$ ratios ranged from 0.54 to $4.70 \mathrm{meq} /$ 
$100 \mathrm{~g}$ and .01 to .25 , respectively. The cypress stands occurred in the most extreme sites chemically, and were composed of fewer species with a greater proportion of serpentine endemics, yet the principal components are not related primarily to the soil chemical variables. The non-cypress stands, on the other hand, occupied the sites that are less extreme chemically, yet the first PC is correlated only with soil chemical variables. Species less adapted to a $\mathrm{Ca}-\mathrm{Mg}$ imbalance, and thus more likely to be responsive to a $\mathrm{Ca}-\mathrm{Mg}$ gradient, can survive on these sites and compete with species favored by the serpentine conditions.

Our success in interpreting environmental pairs as gradients was less in the non-cypress stands than in the cypress stands, and accounted for less of the variation in the principal components. Subsoil variables were more important in the cypress principal components, whereas there was little difference for the non-cypress components except for soil-texture variables, in which the surface variables had more significant relations.

Numerous factors make it very difficult to find the relation between species and environmental gradients. The effect of stand age is unknown in the non-cypress stands and insufficiently accounted for in the cypress stands. Additional unknowns are the suitability of the environmental variables used and whether significant variables were omitted. Fires are an important factor in this type of vegetation, but their effects are not always known (Vogl, 1967; Hanes, 1971). Fire intensity, interval between fires, and conditions after a fire are all "historical" factors that can be very important in determining the composition of vegetation and, thus, interfere with correlations between vegetation and the present environment (Greig-Smith, 1964). Fires also affect the dispersal abilities of species (Wells 1962). Inter-specific interactions can affect the growth of species at a site and can obscure observed relationships with the physicical environment. Finally, interactions of environmental gradients can obscure simple relationships, i.e., the response of a species to gradient A may be different at one end of gradient B from that at the other end of gradient $B$.

Conclusions in an exploratory study of this type must be tentative because of the limited number of stands we were able to study. But the hypotheses generated provide a basis for additional studies. The ease of establishing introduced species might be compared between sites presently occupied by cypress stands and those with non-cypress stands. More intensive studies of the native species could help clarify findings in this study. Bromus laevipes, Melica torreyana, and Sitanion bystrix (grasses found negatively correlated with $\mathrm{Ca}$ status) could be tested for use in establishing a ground cover on cleared serpentine soils. These species were not found in the cypress stands, perhaps due to interspecific interactions. Cypress may exert a strong influence on understory vegetation.

\section{LITERATURE CITED}

AUSTIN, M. P., and I. NOY-MEIR

1971. The problem of non-linearity in ordination: experiments with two-gradient models. J. Ecol. 59:763-73.

BEALS, E. W.

1973. Ordination: mathematical elegance and ecological naivete. J. Ecol. 61:23-34.

BISWELL, $\mathrm{H}$.

1974. Effects of fire on chaparral. In Fire and Ecosystems. T. T. Kozlowski and C. E. Ahlgren, eds., pp. 321-64. New York: Academic Press. 
CONREY, BERT L.

1947. Geology of a southern portion of the Morgan Valley quadrangle, California, scale 1:62,500, University of California, Berkeley. M. A. Thesis (unpublished).

GAUCH, H. G., and R. H. WHITTAKER

1972. Comparisons of ordination techniques. Ecol. 53:868-75.

GEMBORYS, S. R.

1974. The structure of hardwood forest ecosystems of Prince Edward County, Virginia. Ecol. 55:614-21.

GLEASON, H. A.

1926. The individualistic concept of the plant association. Torrey Bot. Club Bull. 53:7-26.

GREIG-SMITH, P.

1964. Quantitative Plant Ecology. London: Butterworth Scientific Publications.

GRIFFIN, J. R., and C. O. STONE

1967. McNab Cypress in Northern California: a geographic review. Madrono 19(1):19-27.

HANES, T. L.

1971. Succession after fire in the chaparral of southern California. Ecol. Monographs 41:27-52.

HARDHAM, C. B.

1962. The Santa Lucia C. Sargentii groves and their associated northern hydrophilous and endemic species. Madrono, 16:173-179.

JONES, M. B., W. A. WILLIAMS, and J. E. RUCKMAN

1977. Fertilization of Trifolium subterraneum L. growing on serpentine soils. Soil Sci. Soc. of Amer. J., 41:87-89.

LOUCKS, O. L.

1962. Ordinating forest communities by means of environmental scalers and phytosociological indices. Ecol. Monographs 32:137-66.

MOORE, A. W., and J. S. RUSSELL

1976. Ordination of soil data. In Pattern Analysis in Agricultural Science. By W. T. Williams, ed. pp. 204-14. Melbourne: CSIRO, and Amsterdam: Elsevier Scientific Publishing Co.

MUNZ, P. A., and D. D. KECK

1959. A California Flora. Berkeley and Los Angeles: Univ. of California Press.

NIE, N., C. H. HULL, J. G. JENKINS, K. STEINBRENNER, and D. H. BENT

1975. SPSS-Statistical Package for the Social Sciences, Second Edition. New York: McGraw-Hill. 675 pp.

PITT, M. D., R. H. BURGY, and H. F. HEADY

1978. Influences of brush conversion and weather patterns on runoff from a northern California watershed. J. Range Manag. 31:23-27.

PROCTOR, J., and S. R. J. WOODELL

1975. The ecology of serpentine soils. Adv. Ecol. Res. 9:255-366.

ROWE, P. B., and L. F. REIMANN

1961. Water use by brush, grass, and grass-forb vegetation. J. Forest. 59:175-81.

RUMMEL, R. J.

1970. Applied Factor Analysis. Evanston: Northwestern Univ. Press.

SELLERS, W. D.

1965. Physical Climatology. Chicago and London: Univ. Chicago Press.

SOIL SURVEY STAFF, SCS, USDA

1972. Soil series of the United States Puerto Rico, and the Virgin Island, their taxonomic classifications. Washington: U. S. Govt. Printing Office.

SPOOMER, G. G.

1973. The concepts of "interaction" and "operational environment" in environmental analysis. Ecol. 54:200-204

TRACEY, J. G.

1969. Edaphic differentiation of some forest types in eastern Australia. I. Soil physical factors. J. Ecol. 57:805-816.

VAN GROENWOOD, $\mathrm{H}$.

1976. Theoretical considerations of the covariation of plant species along ecological gradients with regard to multivariate analysis. J. Ecol. 64:837-46.

VOGL, R. J.

1967. Fire adaptations of some California plants. 7th Ann. Proc. of the Tall Timbers Fire Ecology Conference.

WALKER, B. H., and C. F. WEHRHAHN

1971. Relationships between derived vegetation gradients and measured environmental variables in Saskatchewan Wetlands. Ecol. 52:85-95.

WARING, R. H. and J. MAJOR

1964. Some vegetation of the California coastal redwood region in relation to gradients of moisture, nutrients, light, and temperature. Ecol. Monographs 34:167-212.

WEBB, L. J.

1969. Edaphic differentiation of some forest types in eastern Australia. II. Soil chemical factors. J. Ecol. $57: 812-830$ 
WELLS, P. V.

1962. Vegetation in relation to geological substratum and fire in the San Luis Obispo Quadrangle, California. Ecol. Monographs 32:79-103.

WESTMAN, W. E.

1975. Edaphic climax pattern of the pygmy forest region of California. Ecol. Monographs 45:109-35. WILLIAMS, W. T.

1971. Principles of clustering. Ann. Rev. Ecol. and System. 2:303-24.

WILLIAMS, W. T.

1976. Ordination: Principal component analysis. In Pattern Analysis in Agricultural Science. By W. T. Williams, ed. pp. 47-58, Melbourne: CSIRO, and Amsterdam: Elsevier Scientific Publishing Co. 